\title{
Reconceptualising the Physical Sciences Curriculum and Assessment Policy Statement in a South African Context
}

\author{
Cedric Bheki Mpungose ${ }^{1}$ \\ ${ }^{1}$ School of Education, University of KwaZulu-Natal, Durban, South Africa \\ Correspondence: Cedric Bheki Mpungose, School of Education, University of KwaZulu-Natal, Durban, South Africa.
}

Received: July 15, 2020

Accepted: October 13, 2020

Online Published: November 26, 2020

doi:10.5430/ijhe.v10n2p116

URL: https://doi.org/10.5430/ijhe.v10n2p116

\begin{abstract}
Post-apartheid South African curriculum reforms, from outcomes-based education (OBE) to the Curriculum and Assessment Policy Statement (CAPS), resulted in different challenges. Teachers, in particular those teaching Physical Sciences in the Further Education and Training (FET) phase from Grades 10-12, were expected to cope with changes and master Physical Sciences curriculum for the attainment of good results, but were unable to do so because they were missing an understanding of curriculum concepts. The success of any curriculum depends on ten fundamental and broad curriculum concepts: rationale, goals, activities, assessment, accessibility, resources, content, roles, environment, and time. However, empirical findings show that Grade 12 Physical Science teachers in South African schools still struggle to understand and contextualise curriculum concepts in order to redefine specific CAPS Physical Science concepts. Consequently, this conceptual study uses Van den Akker (2004) curriculum spider web concept framework in reconceptualising Grade 12 CAPS Physical Science concepts. This study argues that teaching without knowing specific subject curriculum concepts can lead to poor teacher performance and poor subject results, this study concludes by proposing a formal, non-formal and informal framework for CAPS Physical Science to resolve this.
\end{abstract}

Keywords: curriculum spider web, formal, informal, non-formal, CAPS Physical Science, South Africa

\section{Introduction}

The reconceptualisation of the curriculum started in the mid-20th century when Tyler (1949b) curriculum paradigm was critiqued as 'traditional', since it focused more on goals to be achieved, content to be covered, organisation/pedagogy, and assessment (Pinar', 1975). As such, curriculum was structured and non-democratic, and teachers were only thought to need to give instruction and deliver the curriculum content to students in order to achieve particular goals (product approach); students only needed to accept what they were taught, without any experiential engagement (Dewey*, 1938; Freire, 1985). This suggests that the more traditional aspects of curriculum were subjectbased, content-driven, and teacher-led.

However, the curriculum was then reconceptualised by critiquing the political and historical influences on its development, and it was then viewed as phenomena experienced by individuals (teachers and students) while addressing personal, societal, or political needs (Pinar- \& Grumet, 1988). This, according to Pinar* (1988), created an understanding - particularly in teacher education - that curriculum development or implementation is influenced by external factors (ruling party politics, curriculum developers, society) and internal factors (teachers and learners). In other words, the experiential aspects of the curriculum weakened content and subject boundaries but emphasised learner independence for personal and social knowledge construction. As a result, "reconceptualisation has ended as a social and intellectual movement within curriculum studies" (Pinar , 1989, p. 93). The term 'reconceptualisation' was first coined by Macdonald (1971) and popularised by Pinar' (1975) as a way to engage in research dialogue in order to redefine what already exists in the field of education. Thus, reconceptualisation of curriculum helped practitioners to "understand the distinctions and similarities among our work [teaching], as much as to inform the mainstream of the field [curriculum] what might be expected from the few of us" (Pinar , 1989, p. 93).

Le Grange and Beets (2005) as well as Jansen- (2001) reconceptualise the South African curriculum by critiquing deep structures of curriculum reforms post-1994. The latter studies further argue that reconceptualisation of curriculum has impacts on teachers, learners, and the community at large, while placing a greater focus on radical transformation for the improvement of teachers' performance and subject results. Fullan (2007) agrees with Fakier and Waghid (2004) that reconceptualisation of curriculum intends that practitioners (teachers) understand the curriculum, not just 
implement and evaluate it according to the plan (policy documents, the Curriculum and Assessment Policy Statement [CAPS]), as this leads to radical transformation of curriculum implementation. This suggests that reconceptualisation of CAPS Physical science may assist teachers to have an in-depth understanding of the subject with its related implementation challenges, in order bring about necessary changes for effective teaching and learning.

Hoadley and Jansen (2014) agree with Pinar^ (1978) etymological definition of the word 'curriculum' as originating from the Greek currere which implies 'to run the course/race' - in other words, to run the course of teaching/learning. As such, curriculum is a "plan for teaching or learning", also known as a syllabus (Van den Akker et al., 2009, p. 9). This is referred to as the curriculum by developers or designers who develop it as a document which is intended and officially planned (Chisholm \& Wildeman, 2013). However, when the curriculum is at the actual implementation stage by teachers, being achieved by learners and assessed (Le Grange' \& Reddy, 2017), it is defined as "a plan of teaching/learning" (Pinar', 2012). This suggests that the reconceptualisation of the Physical Science curriculum requires teachers to understand the different layers of curriculum, including the intended (planned curriculum), implemented (actual curriculum), and achieved (assessed curriculum).

Pinar (2010, p. 7) argues that reconceptualisation of curriculum in post-apartheid South Africa can intervene in "expecting underprepared and overworked teachers in poverty-stricken conditions to achieve predetermined outcomes without detailed curriculum content training amounted to leaving them in a desert with only signposts for survival". Ramrathan- (2010) agrees with Jansen (1998) that the South African education system has undergone various curriculum reforms, and that the introduction of new curriculum policies since 1994 has had a significant impact on the teaching and learning process of each subject. Khoza (2015a) further highlights the importance of the three cycles of curriculum reforms that have occurred in post-apartheid South Africa. Muller and Hoadley (2019) agree with Jansen (1998) that the first cycle took place in 1995, when the National Education and Training Forum introduced a specialised performance-based curriculum called the NATED curriculum. The main objective of NATED was to eradicate and redress outdated and racially biased aspects of apartheid from the existing curriculum. Spaull and Jansen (2019) further assert that an outcome-based education (OBE) approach was used for this new curriculum development in order to enhance learner-centredness. This occurred in both the General Education and Training (GET) (Grades R to 9) and Further Education and Training (FET) (Grades 10 to 12) phases of schooling.

After the NATED curriculum was reviewed, Curriculum 2005 (C2005) was developed using the OBE approach and introduced in 1998 (second cycle); it was radically learner-centred and competence-based, driven by set outcomes, and included a statement of intention to be achieved by learners (Khoza, 2015a; Ramrathan-, 2010). This suggests that there was no specified learning content, but that teachers and learners were expected to select their own content in order to achieve the set outcomes that students needed to achieve life and industry skills. The freedom in selecting content and misunderstanding the range of outcomes, from critical to learning outcomes demanded by C2005 in each subject (such as Physical Science), created confusion among teachers (Khoza-, 2013). This influenced the second postapartheid reform, the Revised National Curriculum Statement in GET, introduced in 2002, and the National Curriculum Statement (NCS) in FET which was introduced in 2003. While still developed through OBE frameworks, the new curriculums included content specification (Hoadley \& Jansen, 2014). The suggests that even in Grade 12 Physical Science there were stipulated topics to be covered through learner-centred approaches (OBE).

The NCS was revised after teachers indicated that the documents were confusing and contradictory. Teachers were struggling to link Learning Outcomes with Assessment Standards, and failing to understand difficult terminology in the policy document. This resulted in the third and final curriculum reform, introduced in 2012 as the CAPS in both GET and FET. Different documents were combined into one comprehensive curriculum document that contains specified subject content and assessment tasks to be covered within particular periods of time (Pinar, 2010). This suggests that the South African curriculum shifted from a competence-based curriculum (outcomes-driven - NCS) to a performance-based curriculum (content-driven - CAPS). The history of South Africa's basic education curriculum is summarised in Table 1.

Table 1. History of South Africa's basic education curriculum

\begin{tabular}{lllll}
\hline Name & Year & Phase & & Approach \\
\hline NATED curriculum & $1990-1994$ & GET & FET & OBE/competence-based \\
Democracy 1994 & & & & \\
C2005 & $1998-2001$ & GET & FET & OBE/competence-based \\
RNCS and NCS & 2002-2011 & GET & FET & OBE/competence-based \\
CAPS & 2012 to date & GET & FET & Performance-based/content-driven \\
\hline
\end{tabular}


Marope (2017) argues that the new paradigm shift is influenced by the rapid change caused by the Fourth Industrial Revolution (Industry 4.0 or 4IR), which seeks curriculum to be reconceptualised and repositioned in order to meet current and future challenges and opportunities. Globally, this suggests that all stakeholders in education should reshape curricula to address the needs of students, teachers and others so that the rapid change will be sustained. Berkvens, van den Akker, and Brugman (2014) further argue that reconceptualisation of curriculum should be holistic, inclusive, just, and sustainable in order to adapt in both the local and international context. Consequently, Marope (2017) outlined that in reconceptualising curriculum, key issues should be considered, including: 1 . The transition to knowledge and technology-driven growth (skill/knowledge-based economy); 2. The broadening concept of development (holistic, inclusive, equitable, just, and sustainable development); 3. Internationally agreed goals for propelling development (Goal 4 emphasises equity of education quality and lifelong learning for all); 4 . New demands of work and workplaces (engineering, medicine, plumbing, teaching, etc.); and 5. Climate change (environmental custodianship). This would require subject teachers to understand each curriculum concept that is to be unpacked in order to address current challenges for the future.

\section{Curricular Concepts}

Van den Akker (1999) states that the word 'curriculum' is often applicable at macro level (national and provincial education ministry) but is especially relevant at meso (school) and micro (the classroom) level, because this is where practical implementation occurs. While the planned curriculum is developed at macro level, with stipulated topics and activities to be covered at a particular period of time, teachers at school and classroom level still grapple with results improvement, and worst of all still fail to balance various components of subjects during implementation and assessment of the curriculum (Van den Akker, 2004; Vermeulen, Volman, \& Terwel, 1997). In resolving this, Walker (2002) agrees with (Tyler, 1949a) that goals, content, organisation of learning, and assessment should be the major components that teachers should focus on for effective teaching and learning. However, curriculum development and implementation, particularly at school or classroom level, is faced with different challenges, such as incomplete syllabus, the wrong teaching and assessment methods and others (Nieveen, Gustafson, Branch, \& Van den Akker, 1999). These challenges influenced van den Akker, Kuiper, and Hameyer (2003) to establish a more comprehensive teaching framework (Table 2), known as the curricular spider web, which stipulates ten fundamental curriculum concepts.

Table 2. Curricular spider web framework (van den Akker et al., 2003)

\begin{tabular}{lll}
\hline Curriculum concept & Question \\
\hline 1. & Rationale or Vision & Why are they teaching? \\
2. Aims \& Objectives & Toward which goals are they teaching? \\
3. Content & What are they teaching? \\
4. Learning activities & How are they teaching? \\
5. Teacher role & How is the teacher facilitating teaching? \\
6. Materials \& Resources & With what are they teaching? \\
7. Grouping & With whom are they teaching? \\
8. Location & Where are they teaching? \\
9. Time & When are they teaching? \\
10. Assessment & How do we measure how far teaching has progressed?
\end{tabular}

Van den Akker et al. (2009) assert that the rationale for teaching forms the core motivation and connects all of the other curriculum concepts together, while the other concepts are connected to each other in order to enhance consistency and coherence. Berkvens et al. (2014) define rationale as a response to the question of why teachers are teaching a particular subject. Kehdinga (2014) study with six student teachers who taught CAPS subjects in schools in Kwa-Zulu Natal, South Africa, discovered that they were driven more by the rationale of completing the subject content (profession/discipline/subject) than by assisting learners (societal rationale) to understand the content. However, findings by Khoza (2015a) on teachers' reflections on their teaching of CAPS subjects in South African schools outlined that their lack of personal rationale, which addresses their self-identity (values, beliefs, love, and selfdirection), contributes to their lack of pedagogy or teaching methods that address their needs. These findings suggest that when addressing the question of why teachers teach (rationale), teachers seek to balance or draw equally from personal rationale (teacher needs), societal rationale (learner needs), and content rationale (subject needs). 
Mpungose (2016, p. 42) defines aims as a "broad general statement of teaching intentions written from the teachers' point of view". This suggests that aims address the question of what destination teachers have in mind for learners, based on a particular curriculum or subject. However, the objectives of any programme are referred to as a "specific statement of teaching intention" which gives direction to the specific subject areas to be covered per block of learning (Kennedy*, Hyland, \& Ryan, 2006, p. 5). This suggests that aims are general subject statements of intention written to address the teachers' needs, while objectives are specific subject statements of intention written to address subject needs. For instance, aims in Physical Science could be to redress the imbalances of the past, while objectives could be to introduce students to scientific and practical work. This, according to Tyler (1949b), is termed goals (statement of intention). Nevertheless, Khoza* (2013) discovered that goals only address the teacher and subject needs, while missing the statement of intention of what the learner is expected to know or demonstrate after completion of the learning programme, known as the learning outcomes. In other words, learning outcomes are competences that are expected to be achieved by learners at the end of a lesson or programme, such as skills, knowledge, and values.

Berkvens et al. (2014) concur with Shulman' (1986) that teaching requires teachers to know and understand the subject topics that are going to be taught. According to Hoadley and Jansen (2014) this is referred to as content and comprises subject knowledge, with all its respective theoretical and practical aspects. Physical Science content is categorised into Physics (vertically organised) and Chemistry (horizontally organised) content (Giancoli, 2005; Hoadley \& Jansen, 2014). Khoza (2019) argues that pragmatically organised subject content (blends both vertical and horizontal content) forms the basis of teaching and helps teachers to teach the content according to their needs at a particular time. This requires teachers to know their role in teaching subject content, because "the professional authority of academic as teachers should rest on the body of knowledge. This comprises of how the subject he/she professes is best learned and taught" (Ramsden, 2003, p. 9). Empirically, a qualitative case study conducted by Khoza' and Biyela (2019) to explore how mathematics and science content is decolonised by CAPS teachers, found that teachers' roles were driven more by the role of being an instructor (give content instructions) and facilitator (guides learners) at the expense of being a researcher (blends roles of instructor and facilitator) to address their needs. Thus, teachers' role preference has an impact on creating and conveying the Physical Science topics/content to learners.

van den Akker', Kuiper, and Hameyer (2003) agree with Black and William (2009) that the definition of assessment includes both quantitative (measurement - quantifying the degree to which a phenomenon possesses a given level) and qualitative (evaluation judging the degree or value of a phenomenon) data from a variety of sources. Assessment seeks to bridge the gap between teaching and learning in order to provide feedback on progress to stakeholders, including students, parents, and lecturers (Kennedy* et al., 2006). Khoza and Biyela (2019) study of teachers' experiences in the teaching of the Lesotho curriculum outlines key points on assessment. The study revealed that teachers were giving learners some reflective activities, asking questions to monitor the progress of teaching and learning (assessment for learning), and allowing students to critique each other's work (assessment as learning). However, they drew more from assessment of learning, which consists of formal tasks for grading drawn from the content taught to address the subject need. Teachers focus more on assessment of learning because good teaching and learning is perceived to be accurate when learners score high marks on tests and examination. As a result, the content is taught to be memorised for summative assessment (Berkvens et al., 2014; Mpungose', 2020a). Moreover, Hoadley and Jansen (2014) argue that most teachers prefer to use teacher-centred activities in order to save time to enable them to finish the syllabus, and to then use the remaining time to drill learners towards assessment of learning. Hence, there are few teachers who opt for learner-centred activities, because these come with different demands, such as an increased requirement for resources and time, and are done for developmental purposes (Berkvens et al., 2014; Ramrathan, 2019). Additionally, drilling learners with the content (content-centred activities) encourages teachers to address each topic of the subject as stipulated in the policy documents (Shulman \& Shulman, 2004).

According to Van den Akker et al. (2009), materials, sometimes called resources, are defined as anything that facilitates teaching and learning or "any person or thing that communicates learning" (Khoza', 2012, p. 75). On the one hand, Van den Akker et al. (2009) and Berkvens et al. (2014) argue that traditional hardware resources, such as textbooks, chalk and chalkboard, paper and pen, form the basis of teaching and learning while modern hardware resources in our digital age, such as computers, data projectors, and smart phones, supplement them. On the other hand, software resources like the internet, learning management systems, and other software applications assist teachers to socially produce and consume information with learners and others (Mpungose*, 2020c; Selwyn, 2016). Khoza (2019) warns that having both hardware and software resources in teaching without ideology or pedagogy (ideological-ware) is meaningless, because teaching activities cannot be executed without a foundation in teaching and learning methods.

Location is sometimes defined as the environment or space provided (per school policy) where teaching-learning can take place, and it is always emphasised that teaching processes should occur within a conducive environment that 
encourages and supports teachers, learners, and subject needs (Khoza, 2019; Van den Akker et al., 2009). Consequently, Berkvens et al. (2014, p. 18) advocate that the teaching and learning process should be "carried out in inspiring environments that provide adequate teaching and learning materials" at particular times. Recent discourses (Clement, 2020; Selwyn, 2016; Van Dijk, 2006) affirm that online learning environments (internet or web-based teaching/learning) supplement the face-to-face teaching/learning environment (demarcated classroom learning) for effective teaching and learning. In other words, learning management systems, video communication technologies and other online applications can easily facilitate learning at any time (in official time, spare time, extra time), irrespective of the demarcated venues/environments such as classrooms and laboratories (Mishra- \& Koehler', 2006; Mpungose-, 2020b). This suggests that blended learning (use of both face-to-face and online methods) can help teachers to draw from their personal needs in order to accommodate learners who come from different economic backgrounds. This is achievable, provided that teachers understand their culture (values, norms, and customs) and that of the community, have physical access (transport and accommodation), and are motivated by the incentives or remuneration they receive from their employer (Hoadley \& Jansen, 2014; Mpungose, 2016). Thus, the discourse on curriculum concepts from the above stated literature suggests propositions of each curriculum concept as depicted in Table 3.

Table 3. Curriculum concept propositions

\begin{tabular}{|c|c|c|}
\hline Curriculum concept & Question & Proposition \\
\hline 1. Rationale or Vision & Why are they teaching? & $\begin{array}{l}\text { - Personal rationale (teacher need) } \\
\text { - Societal rationale (learner need) } \\
\text { - Content rationale (subject need) }\end{array}$ \\
\hline 2. Aims \& Objectives & Toward which goals are they teaching? & $\begin{array}{l}\text { - Aims (teacher need) } \\
\text { - Learning outcomes (learner need) } \\
\text { - Objectives (subject need) }\end{array}$ \\
\hline 3. Content & What are they teaching? & $\begin{array}{l}\text { - Pragmatic (teacher need) } \\
\text { - Horizontal (learner need) } \\
\text { - Vertical (subject need) }\end{array}$ \\
\hline 4. Learning activities & How are they teaching? & $\begin{array}{l}\text { - Teacher-centred activities (teacher need) } \\
\text { - Learner-centred activities (learner need) } \\
\text { - Content-centred activities (subject need) }\end{array}$ \\
\hline 5. Teacher role & How is the teacher facilitating teaching? & $\begin{array}{l}\text { - Researcher (teacher need) } \\
\text { - Facilitator (learner need) } \\
\text { - Instructor (subject need) }\end{array}$ \\
\hline $\begin{array}{l}\text { 6. Materials \& } \\
\text { Resources }\end{array}$ & With what are they teaching? & $\begin{array}{l}\text { - Ideological-ware resources (teacher need) } \\
\text { - Software resources (learner need) } \\
\text { - Hardware resources (subject need) }\end{array}$ \\
\hline $\begin{array}{l}\text { 7. Grouping or } \\
\text { accessibility }\end{array}$ & With whom are they teaching? & $\begin{array}{l}\text { - Cultural access (teacher need) } \\
\text { - Financial access (learner need) } \\
\text { - Physical access (subject need) }\end{array}$ \\
\hline 8. Location & Where are they teaching? & $\begin{array}{l}\text { - Blended (teacher need) } \\
\text { - Online (learner need) } \\
\text { - Face-to-face (subject need) }\end{array}$ \\
\hline 9. Time & When are they teaching? & $\begin{array}{l}\text { - Extra time (teacher need) } \\
\text { - Spare time (learner need) } \\
\text { - Official time (subject need) }\end{array}$ \\
\hline 10. Assessment & $\begin{array}{l}\text { How do we measure how far teaching } \\
\text { has progressed? }\end{array}$ & $\begin{array}{l}\text { - Assessment for learning (teacher need) } \\
\text { - Assessment as learning (learner need) } \\
\text { - Assessment of learning (subject need) }\end{array}$ \\
\hline
\end{tabular}




\section{Towards Specific CAPS Physical Sciences Concepts}

The study conducted by Stacey et al. (2018) to analyse intended science curriculum globally used analysis of 20 years of Trends in International Mathematics and Science Study (TIMSS) data to answer these questions: 1. Have there been changes in intended science curricula over the last 20 years? 2 . If changes do exist, do they support the hypothesis that science curricula are becoming increasingly similar across countries? 3 . Are there groups of countries where curricula are increasingly similar; can the basis of an international core curriculum be identified? The study revealed that different countries have been effecting changes in the science curriculum. However, there were common or similar curricular concepts across the board, even though some countries seemed to have a wider range of science content topics than others. This suggests that reconceptualising of the science curriculum is still needed in order to find balance in the science curriculum both locally and globally.

Furthermore, Mpungose- (2020b) argues that a complete or balanced curriculum should address the formal (subject need), informal (learner need) and non-formal (teacher need) spheres in teaching and learning. According to Khoza (2019), this brings justice to the education profession and society and seeks teachers to use their personal identities when teaching their subjects. This suggests that each CAPS Physical Science concept should be proposed for formal, non-formal and informal systems in order to maintain justice, consistency, coherence and sustainability of the subject (Berkvens et al., 2014). Thus, " if one has content, technological and pedagogical knowledge without reflection on the experiences (informal, formal and non-formal), teaching/learning may be meaningless" (Mpungose-, 2020b, p. 8).

Berkvens et al. (2014) as well as Mishra- and Koehler' (2006) argue that the intended curriculum is determined by the subject topics (what content or subject matter needs to be taught) planned for implementation. This suggests that each teaching subject needs to include explicit subject topics stipulated in an official policy document, and teachers are expected to be subject experts for effective teaching and learning. Giancoli (2005) as well as Govender and Govender (2014) affirm that science content can be separated into Physics and Chemistry content as well as practical content (experiments). Consequently, in the context of this study, CAPS (2011) outlines content in Physics (Mechanics, Waves, Sound \& Light, Electricity \& Magnetism, Matter \& Materials 1); Chemistry (Chemical Systems, Chemical Change, and Matter \& Materials 2); and practical activities (both in Physics and Chemistry). Physics is influenced by formal content (scientific/vertical knowledge) since it deals with structures of matter and its motion and it uses systematic and scientific equations to prove how the world behaves (Govender \& Govender, 2014; Hoadley \& Jansen, 2014). As such, teachers' roles need to be more instructor-orientated, even though this is not outlined in the Physical Science CAPS document (Hoadley \& Jansen, 2014; Mpungose, 2016). However, Chemistry is influenced by formal content (everyday/ horizontal knowledge) since it studies matter which helps humans to understand how substances react, which is produced through practical experimentation (Hoadley \& Jansen, 2014; Lederman, 1992). This suggests that teachers' role needs to be that of a facilitator for teaching this content. CAPS (2011) on Physical Science outlines practical activities, drawing from both Chemistry and Physics (non-formal or pragmatic content), per term, some formal (for grading) and others informal (not for grading). This suggests that teachers' role here needs to be that of a researcher in order to do research before a practical activity is demonstrated to the learners.

Kennedy* et al. (2006) argue that assessment helps teachers to measure teaching progress and evaluate if the curriculum goals (aims, objectives, and learning outcomes) are achieved. This suggests that "assessment is something lecturers [teachers] do with students and for students [learners] including themselves" for an effective teaching and learning processes to be attained (Mpungose, 2018, p. 173). Consequently Black and William (2009) further assert that in every teaching subject assessment may range from assessment for learning (teacher need), assessment of learning (subject need), and assessment as learning (learner need). However, according to CAPS (2011, p. 106) on Physical Science, "assessment should be both informal (Assessment for Learning) and formal (Assessment of Learning)". The document further outlines observations, classroom dialogue, practical demonstrations, and learner-teacher conferences as ways to enhance informal assessment. Thus, informal assessment can be implemented for improving lessons but not for grading. However, formal assessment tasks range from tests to examinations, practical tasks, projects and demonstrations, and can be utilised for the purpose of grading in order to determine if knowledge of the content is properly achieved by students. While the Physical Science CAPS document is silent on assessment as learning, Reddy and le Grange (2017) aver that this kind of assessment involves informal activities, where learners socialise and assess the work of other learners or groups of learners by following particular criteria or memoranda, that can be termed peer assessment. According to Kennedy (2006), peer assessment can constitute attributes from both assessment of and for learning(non-formal).

Mpungose (2016, p. 42) argues that "goals are an important aspect of the planning of teaching and learning practice" in order to enhance justice in any educational programme. Consequently, misunderstanding of curriculum goals 
stipulated in an official curriculum document (CAPS) may lead to nonfulfillment of desired teaching and learning intentions, since goals "justify the means of doing something" (Nkohla, 2017, p. 76). The literature asserts that goals that drive the teaching and learning process should be determined by aims (non-formal - teachers' general statement), objectives (formal - specific subject statement), and learning outcomes (informal - learners' statement) (Kennedy, 2006; Khoza*, 2013). Nevertheless, CAPS (2011) on Physical Sciences provides general aims for aims, and specific aims for objectives. For instance, Physical Science general aims intend to equip learners with "knowledge, knowledge, skills, and values necessary for self-fulfilment, and meaningful participation in society as citizens of a free country" CAPS (2011, p. 3), while specific aims intend to "equip learners with investigating skills relating to physical and chemical phenomena" CAPS (2011, p. 6). Mpungose (2016) discovered that, unlike the C2005 and NCS curriculums, the CAPS document included no prescribed learning outcomes. Instead CAPS stipulates skills (learning outcomes) that are expected to be achieved by learners. As such, Bloom (1956) argues that learning outcomes are generated according to Bloom's taxonomies (cognitive levels) of learning, namely: knowledge, comprehension, applying, analysing, synthesising, and evaluating. In support of this, CAPS (2011, p. 116) asserts that teachers teaching Physical Science should adhere to a "hierarchy of cognitive levels [Bloom's taxonomies] that can be used to ensure tasks include opportunities for learners to achieve at various levels".

Berkvens et al. (2014) argue that time is about periods at which content is taught, while locations are where or the environment in which the content is taught. Studies outline that Physical Sciences teachers struggle to finish the allocated content within a specified or official period of time (formal) as stipulated in the CAPS document, because of insufficient time allocated for this (Khoza, 2015b; Mpungose, 2016). As a result, teachers are forced to organise morning or afternoon classes (informal), even during their own spare time over weekends or holidays (non-formal), to cover all the content (Govender \& Govender, 2014).

Khoza (2019) outlines that almost all South African schools offer their classes in formal demarcated classrooms or laboratories (for face-to-face classes) because of insufficient access to internet resources for online (informal) classes. However, blended learning (non-formal) is possible, particularly in well-resourced schools (Waghid- \& Davids, 2016). Contact time allocated to teach content, skills, and practical work for Grade 12 Physical Science is " 4 hours per week, with 40 weeks in total per grade" (CAPS, 2011, p. 9). However, CAPS Physical Science is silent when determining teachers' use of spare time and extra time for teaching because of issues related to transport and accommodation (physical access - formal), community (culture: urban, township or rural - non-formal), and remuneration (financial access - informal) of Physical Science teachers. This may contribute to ineffective teaching and learning, which may affect teachers' performance and indicates the need for spare time and extra time to be considered within the CAPS document. Moreover, one of the shortcomings of the CAPS Physical Science document is that it does not specify location/environment, but assumes that learning is done in a classroom context (face-to-face). In overcoming this, Mpungose (2016) and Le Grange' and Reddy (2017) argue that specifying the environment as in a classroom, laboratory, online, or blended can assist teachers with proper planning.

Waghid, Manthalu, Terblanche, Waghid, and Waghid (2020) argue that in the South African context, private schools (which receive no funding from government) possess more teaching resources than public schools, and as such some teachers prefer teaching in private schools. Mpungose (2016) found that the CAPS Physical Science document outlines different kinds of resources that can be utilised for teaching and learning, without any assurance that schools have access to these. Evidently, CAPS (2011) does specify resource materials to be used per content section, particularly where practical demonstration is required. For instance, batteries, connecting wires, several resistors of different values, a voltmeter, ammeter, and switches are suggested for practical work demonstration within electric circuit sections. However, the Physical Science CAPS document is silent on other physical resources (formal) such as textbooks, computers/smartphones, and software resources (informal) like the internet and other software applications that can be used for content dissemination in the digital age. As such Khoza (2015b) further argues that even though ideological-ware (teaching methods - non-formal) such as demonstration, discussion, and simulation are stipulated in the CAPS document, the majority of teachers are not aware of them because their focus is on the teaching activities needed to complete the syllabus.

Teaching activities carried out in any subject should address the needs of the subject, the teacher/learner, and of society (Bernstein, 1999; Van den Akker et al., 2009). In other words, teaching activities must be problem-centred (learnercentred/informal), content-centred (subject-centred/formal), and personal-centred (teacher-centred/non-formal). This suggests that teaching activities should be made to address the needs of all school stakeholders; thus each stakeholder is expected to contribute to the successful execution of a subject (Hoadley \& Jansen, 2014). In the context of CAPS Physical Science, formal teaching activities include all those that can be recorded for grading purposes, such as projects, control tests, practical work and others, while informal activities include those done for developmental 
purposes, such as home or class work investigations, experiments, informal tests and others (CAPS, 2011). There are also recorded or unrecorded practical activities given to students and teachers, who interpret them based on personal observation. Even though the CAPS document on Physical Science is silent when it comes to teachers' roles, studies further argue that these are determined by the activities completed in lessons. Hoadley and Jansen (2014) assert that formal activities are influenced by performance curriculum (content), and this requires teachers to give instructions (teachers' role as instructor - formal) to learners to execute particular activities. Informal activities are influenced by the competence curriculum (learners), and teachers are expected to guide learners in facilitating (informal) activities while the teachers act as researchers (non-formal) in order to discover new discourses in the subject field.

Palmer (2017) argues that the question of teaching is mostly centred around four fundamental questions: 1. What content do I teach (content)? 2. How can I teach this content (teaching methods)?; 3. Who is the self that teaches (role)?; and 4. Why am I teaching this content (drive/rationale/motive)? Consequently, (Khoza, 2015b; Michalec, 2013) assert that failing to address the philosophical 'why' question, which advocates for the motive or rationale behind their teaching, may lead to vulnerability of the curriculum. This suggests that even if teachers can execute all other Physical Science concepts (Table 4) successfully, if they miss the rationale, which forms the inner-self in teaching, this might harm the teaching process. Khoza (2015b) argues that the rationale forms teachers' inner-self domain, which can lead to situations where teachers have the drive and motivation behind teaching their subjects because of selfidentity, which gives them direction (passion and flexibility). Consequently, as (CAPS, 2011, p. 6) states:

Physical Sciences investigate physical and chemical phenomena. This is done through scientific inquiry, application of scientific models, theories and laws in order to explain and predict events in the physical environment. This subject also deals with society's need to understand how the physical environment works in order to benefit from it and responsibly care for it. All scientific and technological knowledge, including Indigenous Knowledge Systems (IKS) ...

This suggests that the rationale behind teaching Physical Science in CAPS is influenced by the scientific rationale (formal), application rationale (informal) and indigenous rationale (non-formal). Thus, CAPS Physical science should be influenced by both physical and chemical scientific knowledge that can be applied in their own context using available technological and indigenous knowledge systems.

Table 4. CAPS Physical Science formal, non-formal and informal frameworks

\begin{tabular}{|c|c|c|c|}
\hline \multicolumn{4}{|c|}{ Specific CAPS Physical Science concepts } \\
\hline & $\begin{array}{l}\text { Formal } \\
\text { (subject need) }\end{array}$ & $\begin{array}{l}\text { Non-formal } \\
\text { (teacher need) }\end{array}$ & $\begin{array}{l}\text { Informal } \\
\text { (learner need) }\end{array}$ \\
\hline 1. Rationale & Scientific rationale & Indigenous rationale & Application rationale \\
\hline 2. Goals & Specific aims & General aims & Skills \\
\hline 3. Content & Physics & Practical/experiments & Chemistry (horizontal) \\
\hline 4. Learning activities & Formal activities & Practical activities & Informal activities \\
\hline 5. Teacher role & Instructor & Researcher & Facilitator \\
\hline 6. Resource material & Physical resources & Teaching methods & Internet resources \\
\hline 7. Accessibility & Transport/accommodation & Urban/township/rural & Remuneration \\
\hline 8. Environment & Classroom/laboratory & Classroom/laboratory /internet & Internet \\
\hline 9. Time & Contact time & Holiday classes & Morning/afternoon classes \\
\hline 10. Assessment & Formal assessment & Peer assessment & Informal assessment \\
\hline
\end{tabular}

\section{Conclusion and Implications for Education}

This study used van den Akker' et al. (2003) curricular spider web framework to reconceptualise the CAPS FET Physical Science curriculum in a South African context. The framework outlined ten fundamental and broad curriculum concepts that needs to be considered in order to reconceptualise any curriculum, which includes rationale, goals, activities, assessment, accessibility, resources, content, roles, environment, and time. In reconceptualising CAPS Physical Science, the study synthesised ten specific curriculum concepts that need to be understood for effective teaching and learning in order to ensure good results.

Reflecting on the past South African curriculum reforms and anticipating the future suggests that teachers ought to be cognizant of the specific Physical Science CAPS concepts, in order to ensure inclusivity, flexibility, effective teaching, 
and successful subject performance. Consequently, the formal, non-formal, and informal frameworks for CAPS Physical Science prove to be the best that can be used by teachers, particularly in a South African context, to bring justice and sustainability and to enhance good performance and results. In other words, the framework can assist teachers to be inclusive in their approaches, in order to tackle challenges faced during curriculum development and implementation.

\section{References}

Berkvens, J., van den Akker, J., \& Brugman, M. (2014). Addressing the quality challenge: Reflection on the post-2015 UNESCO EDUCATION AGENDA. National Commission for UNESCO, 1(2014), 1-30.

Bernstein, B. (1999). Vertical and horizontal discourse: An essay. British Journal of Sociology of Education, 20(2), 157-173. https://doi.org/10.1080/01425699995380

Black, P., \& William, D. (2009). Developing the theory of formative assessment. Educational Assessment, Evaluation and Accountability (formerly: Journal of Personnel Evaluation in Education), 21(1), 5-31. https://doi.org/10.4135/9781446250808.n13

Bloom, B. (1956). Taxonomy of educational objectives: The classification of educational goals.

CAPS. (2011). National curriculum statement grades 10-12: Physical sciences. Pretoria: Government Printer.

Chisholm, L., \& Wildeman, R. (2013). The politics of testing in South Africa. Journal of Curriculum Studies, 45(1), 89-100. https://doi.org/10.1080/00220272.2012.755710

Clement, J. (2020). Most popular social networks worldwide as of January 2020, ranked by number of active users. Retrieved from https://www.statista.com/statistics/272014/global-social-networks-ranked-by-number-of-users

Dewey*, J. (1938). Education and experience. New York: Simon and Schuster.

Fakier, M., \& Waghid, Y. (2004). On Outcomes-Based Education and Creativity in South Africa. International Journal of Special Education, 19(2), 53-63.

Freire, P. (1985). The politics of education: Culture, power, and liberation: Greenwood Publishing Group.

Fullan, M. (2007). The new meaning of educational change. London Routledge.

Giancoli, D. C. (2005). Physics: principles with applications. London: Pearson Education.

Govender, N., \& Govender, D. (2014). Change of Science Teachers' Use of Information and Communication Technology (ICT) Media Resources and its Pedagogical Use in Science Classrooms in a Developing Country. Journal of communication, 5(155-167). https://doi.org/10.1080/0976691x.2014.11884835

Hoadley, U., \& Jansen, J. (2014). Curriculum: Organizing knowledge for the classroom. Cape town: Oxford University Press Southern Africa.

Jansen-, J. (2001). Explaining non-change in education reform after apartheid: Political symbolism and the problem of policy implementation. Implementing education policies: the South African experience, 271-292. https://doi.org/10.1080/02680930110116534

Jansen, J. D. (1998). Curriculum reform in South Africa: A critical analysis of outcomes-based education. Cambridge Journal of Education, 28(3), 321-331. https://doi.org/10.1080/0305764980280305

Kehdinga, G. (2014). Curriculum Theorizing and individualism: An exploration of the curriculum's relation to the social, personal and political dimensions of schooling. Mevlana International Journal of Education, 4(2), 123132.

Kennedy, D. (2006). Writing and using learning outcomes: a practical guide: University College Cork.

Kennedy*, D., Hyland, A., \& Ryan, N. (2006). Writing and Using Learning Outcomes: A Practical Guide. Bologna: European Higher Education Area (EHEA).

Khoza', S. (2012). Who helps an online facilitator to learn with students in a day. Mevlana International Journal of Education, 2(2), 75-84. https://doi.org/10.13054/mije.13.09.3.2

Khoza', S., \& Biyela, A. T. (2019). Decolonising technological pedagogical content knowledge of first year mathematics students. Education and Information Technologies, 1-15. https://doi.org/10.1007/s10639-01910084-4 
Khoza-, S. (2013). Learning Outcomes as Understood by" Publishing Research" Facilitators at a South African University. Online Submission, 3(2), 1-11. https://doi.org/10.13054/mije.13.09.3.2

Khoza, S. (2015a). Student teachers' reflections on their practices of Curriculum and Assessment Policy Statement. South African Journal of Higher Education, 29(4), 179-197. https://doi.org/10.20853/29-4-512

Khoza, S. (2015b). Using curricular spider web to explore a research facilitator's and students' experiences. South African Journal of Higher Education, 29(2), 122-143. https://doi.org/10.20853/29-2-471

Khoza, S. (2019). Lecturers' reflections on curricular spider web concepts transformation strategies. Transformation of Higher Education Institutions in Post-Apartheid South Africa, 1(2019), 15-26. https://doi.org/10.4324/9781351014236-2

Khoza, S., \& Biyela, A. T. (2019). Decolonising technological pedagogical content knowledge of first year mathematics students. Education and Information Technologies, 2020(1), 1-15. https://doi.org/10.1007/s10639019-10084-4

Khoza*, S. (2013). Learning Outcomes as Understood by" Publishing Research" Facilitators at a South African University. Online Submission, 3(2), 1-11. https://doi.org/10.13054/mije.13.09.3.2

Le Grange, L., \& Beets, P. (2005). (Re) conceptualizing validity in (outcomes-based) assessment. South African Journal of Education, 25(2), 115-119.

Le Grange', L., \& Reddy, C. (2017). Curriculum development and design, in L. Ramrathan, L. Le Grange, and P. Higgs, (Eds.), Education Studies: for Initial Teacher Development. Cape Town: Juta \& Company (Pty) Ltd.

Lederman, N. G. (1992). Students' and teachers' conceptions of the nature of science: A review of the research. Journal of research in science teaching, 29(4), 331-359. https://doi.org/10.1002/tea.3660290404

Macdonald, J. B. (1971). Curriculum theory. The Journal of Educational Research, 64(5), 196-200. https://doi.org/10.1080/00220671.1971.10884138

Marope, M. (2017). Reconceptualizing and repositioning curriculum in the 21st century: A global paradigm shift. Retrieved from http://www.ibe.unesco.org/en/news/documentreconceptualizing-and-repositioning-curriculum21st-century

Michalec, P. (2013). Common Core and inner core. Curriculum \& Teaching Dialogue, 15(1/2).

Mishra-, P., \& Koehler', M. J. (2006). Technological pedagogical content knowledge: A framework for teacher knowledge. Teachers college record, 108(6), 1017. https://doi.org/10.1111/j.1467-9620.2006.00684.x

Mpungose', C. (2020a). Beyond limits: Lecturers' reflections on Moodle uptake in South African universities. Education and Information Technologies, 2020(1), 1-20. https://doi.org/10.1007/s10639-020-10190-8

Mpungose-, C. (2020b). Is Moodle or WhatsApp the preferred e-learning platform at a South African university? Firstyear students' experiences. Education and Information Technologies, 25(2), 927-941. https://doi.org/10.1080/18146627.2018.1479645

Mpungose, C. (2016). Teachers' Reflections of the Teaching of Grade 12 Physical Sciences CAPS in Rural Schools at Ceza Circuit. (M. Ed. Thesis), University of KwaZulu-Natal, Durban.

Mpungose, C. (2018). Exploring Lecturers' Reflections on the Use of Moodle to Teach Physical Science Modules at a South African university. (PhD.), UKZN, Durban (214581960).

Mpungose*, C. (2020c). Is Moodle a platform to decolonise the university curriculum? Lecturers' reflections. Africa Education Review, 1(2019), 1-16. https://doi.org/10.1007/s10639-019-10005-5

Muller, J., \& Hoadley, U. (2019). Curriculum Reform and Learner Performance: An Obstinate Paradox in the Quest for Equality. South African schooling: The enigma of inequality (pp. 109-125): Springer. https://doi.org/10.1007/978-3-030-18811-5_6

Nieveen, N., Gustafson, K., Branch, R. M., \& Van den Akker, J. (1999). Design approaches and tools in education and training. London: Kluwer Academic Publisher.

Nkohla, M. (2017). Educators' Reflections on their Practices of Agricultural Sciences Curriculum and Assessment Policy Statement. (Masters' Degree full dissertation), Univesity of KwaZulu-Natal.

Palmer, P. J. (2017). The courage to teach: Exploring the inner landscape of a teacher's life. John Wiley \& Sons. 
Pinar*, W. (1988). The Reconceptualization of Curriculum Studies, 1987: A Personal Retrospective. Journal of curriculum and supervision, 3(2), 157-167. https://doi.org/10.4135/9781412958806.n387

Pinar', W. (1975). Curriculum Theorizing: The Reconceptualists. Berkeley, CA: McCutchan.

Pinar, W. (2010). Curriculum studies in South Africa: Intellectual histories and present circumstances. New York: Springer. https://doi.org/10.1057/9780230105508

Pinar-, W., \& Grumet, M. (1988). Socratic caesura and the theory-practice relationship. Contemporary curriculum discourses, 1988(1), 92-100.

Pinar^, W. (1978). The Reconceptualisation of Curriculum Studies. Journal of Curriculum Studies, 10(3), $205-214$. https://doi.org/10.1080/0022027780100303

Pinar', W. (2012). What is curriculum theory? New York.: Routledge. https://doi.org/10.4324/9781410609793

Pinar , W. (1989). A reconceptualization of teacher education. Journal of Teacher Education, 40(1), 9-12. https://doi.org/10.1177/002248718904000103

Ramrathan-, L. (2010). From response to theorizing: Curriculum genesis in South Africa from the perspective of critical incidence autoethnography Curriculum Studies in South Africa (pp. 107-124): Springer. https://doi.org/10.1057/9780230105508_4

Ramrathan, L. (2019). Pedagogy and Curriculum. Urbana-Champaign: University of Illinois.

Ramsden, P. (2003). Learning to teach in higher education. London: Routledge. https://doi.org/10.4324/9780203507711

Reddy, C., \& le Grange, L. (2017). Assessment and curriculum. In L. Ramrathan, L. Le Grange, \& P. Higgs (Eds.), Education Studies: for Initial Teacher Development (pp. 159-173). Cape Town: Juta \& Company (Pty) LTD.

Selwyn, N. (2016). Minding our language: why education and technology is full of bullshit... and what might be done about it. London: Taylor \& Francis. https://doi.org/10.1080/17439884.2015.1012523

Shulman', L. (1986). Those who understand: Knowledge growth in teaching. Educational researcher, 15(2), 4-14. https://doi.org/10.3102/0013189x015002004

Shulman, L. S., \& Shulman, J. H. (2004). How and what teachers learn: a shifting perspective. Journal of Curriculum Studies, 36(2), 257-271. https://doi.org/10.1080/0022027032000148298

Spaull, N., \& Jansen, J. D. (2019). South African Schooling: The Enigma of Inequality. New York: Springer. https://doi.org/10.1007/978-3-030-18811-5

Stacey, O., De Lazzari, G., Grayson, H., Griffin, H., Jones, E., Taylor, A., \& Thomas, D. (2018). The Globalization of Science Education and Science Curricula: Discussion and Conclusions. The Globalization of Science Curricula (pp. 73-88). Springer. https://doi.org/10.1007/978-3-319-71532-2_5

Tyler, R. (1949a). Basic principles of curriculum and instruction. Chicago: University of Chicago Press.

Tyler, R. (1949b). Basic principles of curriculum and instruction: University of Chicago Press.

Van den Akker, J. (1999). Principles and methods of development research Design approaches and tools in education and training (pp. 1-14). Springer. https://doi.org/10.1007/978-94-011-4255-7_1

Van den Akker, J. (2004). Curriculum perspectives: An introduction Curriculum landscapes and trends (pp. 1-10). Springer. https://doi.org/10.1007/978-94-017-1205-7_1

Van den Akker, J., de Boer, W., Folmer, E., Kuiper, W., Letschert, J., Nieveen, N., \& Thijs, A. (2009). Curriculum in developmentEn: Netherlands Institute for Curriculum Development. Netherlands: Spring.

van den Akker', J., Kuiper, W., \& Hameyer, U. (2003). Curriculum landscapes and trends. Netherlands Springer. https://doi.org/10.1007/978-94-017-1205-7

Van Dijk, J. A. (2006). Digital divide research, achievements and shortcomings. Poetics, 34(4-5), 221-235. https://doi.org/10.1016/j.poetic.2006.05.004

Vermeulen, A., Volman, M., \& Terwel, J. (1997). Success factors in curriculum innovation: mathematics and science. Curriculum and Teaching, 12(2), 15-28. https://doi.org/10.7459/ct/12.2.03

Waghid-, Y., \& Davids, N. (2016). Educational Leadership as Action: Towards an Opening of Rhythm. South African Journal of Higher Education, 30(1), 123-137. https://doi.org/10.20853/30-1-554 
Waghid, Y., Manthalu, C. H., Terblanche, J., Waghid, F., \& Waghid, Z. (2020). In Becoming Reflexive: Implications for Education Cosmopolitan Education and Inclusion (pp. 105-120). Springer. https://doi.org/10.1007/978-3-03038427-2_9

Walker, D. F. (2002). Fundamentals of curriculum: Passion and professionalism. London: Routledge. https://doi.org/10.4324/9781410606259

\section{Copyrights}

Copyright for this article is retained by the author(s), with first publication rights granted to the journal.

This is an open-access article distributed under the terms and conditions of the Creative Commons Attribution license (http://creativecommons.org/licenses/by/4.0/). 